\title{
SUPERVISING HEAD OF SCHOOLS IN IMPROVEMENT OF PROFESSIONAL COMPETENCE TEACHER
}

\author{
Rusni ${ }^{1}$ 压, Heru Setiawan 2 四 \\ ${ }^{1}$ Department of Islamic Education Management, Postgraduate UIN STS Jambi, Indonesia \\ 2 Islamic Religious Education Study Program, STAI An-Nadwah Kuala Tungkal, Indonesia
}

DOI: https://doi.org/10.29121/granthaalayah.v9.i3.2021.3772

Article Type: Research Article

Article Citation: Rusni, and Heru Setiawan. (2021). SUPERVISING HEAD OF SCHOOLS IN

IMPROVEMENT OF PROFESSIONAL COMPETENCE TEACHER.

International Journal of Research GRANTHAALAYAH, 9(3), 170-177. https://doi.org/10.29121/granthaa layah.v9.i3.2021.3772

Received Date: 03 March 2021

Accepted Date: 31 March 2021

Keywords:

Principal Supervision

Teacher Professional Competence

\begin{abstract}
The school principal has been unable to carry out his duties as a supervisor optimally, $t$ Objective of this research is to find out why the head of the School is not optimal in carrying out duties as supervis or . Determination of the subject using purposive sampling technique. This study uses a qualitative approach with data collection methods, namely observation, interviews and documentation. Data analysis techniques include data reduction, data presentation and verification / drawing conclusions, while checking the validity of the data is done by extending observations, observation accuracy, and triangulation. The findings in this study indicate that the principal considers the teacher to have professional competence obtained from his education, the principal considers that the implementation of supervision is not so important, and the principal himself does not know about optimal supervision. The conclusion is that the principal has not performed his duties as a supervisor optimally because the principal thinks the teacher already has professional competence obtained from his education so that the implementation of supervision is not so important. The principal should make a class visit to observe the learning process directly, then conduct individual talks to solve the problems faced by the teacher, and the principal programmatically conducts learning simulations for the teacher to observe.
\end{abstract}

\section{INTRODUCTION}

Educational supervision or better known as educational supervision has a basic concept that is interconnected. Education is different from teaching, education is a maturation process carried out by an educator to students by providing positive stimuli that include cognitive, affective, and psychomotor. Whereas teaching only includes cognitive means that teaching is a process of transferring knowledge without shaping the attitudes and creativity of students. Therefore, education must be supervised or supervised by a supervisor who can be called the principal and other supervisors in the Ministry of Education.

Controlling is the process of evaluating results in relation to plans or objections and deciding what action, if any, to take. (Daft, 2010) Supervision here is supervision that aims to improve the performance of educators and other school personnel by way of giving a good directives and guidance and input on ways or methods of educating good and professional. In its development, educational supervision has a good influence on the development of education in Indonesia so that educators have the ability to teach professionally.

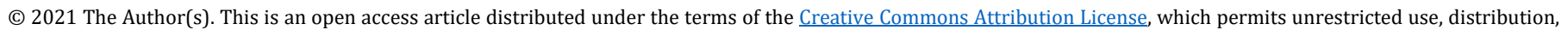
and reproduction in any medium, provided the original author and source are credited. 
The word professional has stuck with it for a long time after people realized that a special job that always has a positive or negative impact must be done seriously. Teachers are also defined as professional officials, because they are given professional allowances (Made Pidarta, 2006). The teacher is one of the human elements in the educational process. The human element is the student. Teachers and students are in a psychological relationship. Both are in a process of educational interaction with different tasks and roles (Djamarah, 2002) . Therefore, the teacher can be declared superior and professional, if the teacher is able to develop individual competencies and does not depend much on other people or on external forces.

To find out the extent to which the teacher is able to carry out learning in the educational process, periodically the principal needs to carry out supervision activities, which can be done through class visits to observe the learning process directly. Especially in the selection and use of methods, the media used and student involvement in the learning process. From the results of this supervision, it can be seen that the weaknesses and strengths of the teacher in implementing learning, the level of mastery of the competence of the teacher concerned. Furthermore, efforts are made for specific solutions, guidance and follow-up. And the next step, programmed in doing simulation learning to be observed by the teacher. Thus, teachers can correct existing deficiencies while maintaining excellence in implementing learning.

Supervision carried out by the principal is of course not only limited to creating an effective teaching and learning atmosphere, but more than that, the principal must also really know whether the creation of an effective teaching and learning atmosphere can be felt by each teacher council and the pupil completely. Supervisors provide rewards for good performance, help employees obtain necessary resources, and protect employees from unnecessary distractions and supervisors have good personalities, as well as values and beliefs similar to the employees' philosophies . (Colquitt, Lepine, 2009)

Previous research is oriented towards the strategy of supervision towards improving teacher quality. The quality of the teacher refers to the performance so that supervision can be related to the quality of the teaching and learning process. However, this study is different from previous research, in that it emphasizes substantially more on the supervision of the principal in increasing the professional competence of teachers. The results of the supervision carried out by the principal can be a reference in coaching teachers in an effort to improve teacher professionalism.

The research journey found that first the principal had not supervised class visits to observe learning activities directly, the two principals had not carried out supervision through individual talks to provide counseling to teachers, the three principals had not supervised through programmed learning simulations.

Based on the journey of the research, the study is considered very important to do, as the main reason that knowing why the Head of School is not optimal in carrying out his duties as supervis or, when it is one of the competencies that must be implemented in order to increase the professionalism of teachers who in turn will improve the quality of the process and learning outcomes with indicators of increasing student absorption of the material given. To achieve that, it is believed that appropriate and continuous guidance based on the results of supervision will contribute to the improvement of the quality of learning for teachers.

\section{MATERIALS AND METHODS}

This study used qualitative research methods. The reasons for her is because of this research data generated in the form of descriptive data obtained from the data in the form of writing, the words and documents emanating from informants who researched and trustworthy.

The location of this research is at MAN 4 Muaro Jambi . The subjects in this study were the principal, teachers, several students and other personnel who were deemed necessary to be involved. In this study, researchers used three data collection techniques, namely observation, interviews and documentation.

The data analysis used in this study is opinion (Miles \& Huberman, 2009) . The first stage of data analysis is collecting data. After that, enter the data reduction stage or filter important data related to the problem under study. Next is the stage of presentation of data, presentation of data is done by way of collating information from data that has been screened in the previous step in the form of text or narration. The last stage is drawing conclusions and data verification, the researcher draws conclusions based on reduced data then presented which is supported by the data and evidence obtained when conducting the research. The analysis steps are shown in the following figure: 


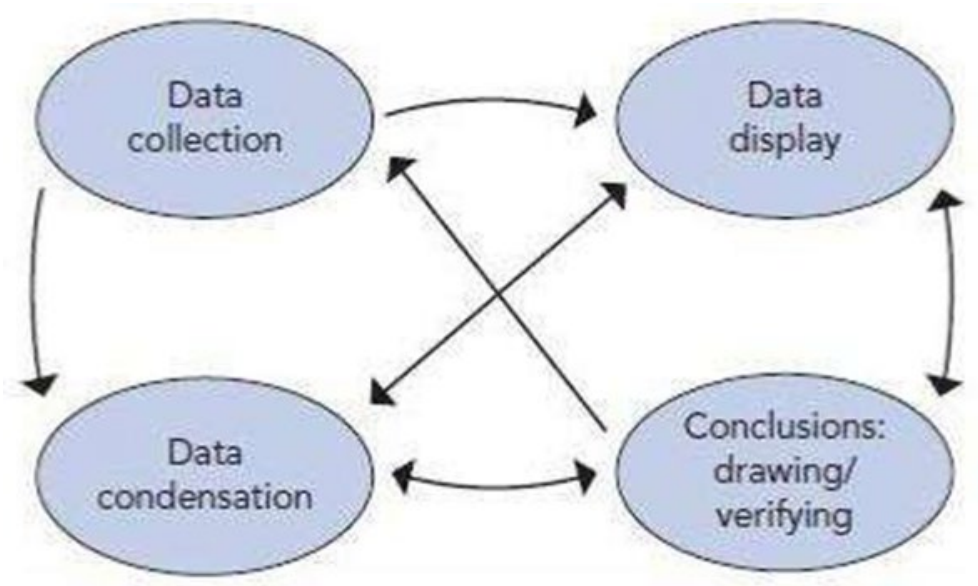

The technique of checking the validity of the data in this study used three techniques, namely: (1) Extension of observations, (2) Increasing observation persistence and (3) Triangulation. The observation was extended until the saturation of data collection was reached. Persistence of observations by researchers can provide depth with continuous careful and detailed observations of salient factors. Triangulation is a data validity checking technique that utilizes something other than the data for checking purposes or as a comparison to the data that has been collected (Ibrahim, 2015).

\section{RESULTS AND DISCUSSION}

\subsection{CLASSROOM VISITS SUPERVISION HEAD OF SCHOOL}

The results of the data analysis research me pointing right that the head of the school MAN 4 Muaro Jambi only do classroom visits formality to see the learning process passing, with no observed directly, as if just want to ensure the presence of the teacher alone, without regard to the implementation of the learning process carried out by teachers in the classroom together with their students .

According to (Mulyasa, 2005) , supervision of class visits can be used by the principal as a technique to observe learning activities directly. Class visits are a very useful technique for obtaining information directly about various matters related to teacher professionalism in carrying out their main teaching duties, especially in the selection and use of learning methods, the media used by teachers in learning, and the involvement of students in learning, as well as know firsthand the ability of students in capturing the material being taught.

The implementation of direct supervision of class visits to the learning process is one of the duties of a school principal to see to what extent the professional level of teachers in carrying out learning, so as to obtain the necessary data in the context of teacher guidance. And this data is used as reference material when the principal provides guidance to the teacher who still needs guidance in the implementation of the learning process so that the professional level of the teacher increases.

Class visits and observations are very useful to obtain information about the teaching and learning process directly, both regarding its strengths and weaknesses and weaknesses. The results of these classroom observations can be used by the supervisor and the teacher to determine the most appropriate ways to improve and improve learning conditions. For class visits to be effective, they should be carefully prepared and carried out with care and in good appearance.

Supervision carried out by the principal of the professional competence of teachers is really necessary because it relates to the character of students who will be produced from the learning process that takes place while in school, especially lately there have been many deviations in the behavior of students which are influenced by various kinds such as electronic media, the environment and others which cause the character of the students to degenerate.

As an education supervisor, the principal of MAN 4 Muaro Jambi does not remain silent about the moral problems of children in school, even though by supervising the learning process from outside the classroom, the principal always reminds the teacher to always add references in the learning process, don't just focus only on the 
use of worksheets when providing material. Thus with the aim of increasing the professional competence possessed by the teacher.

The behavior of carrying out supervision when conducting supervision, in order to successfully provide assistance, it is necessary to conduct an analysis first. Analysis of the teachers will be supervised, meant that action in helping right on target. The behavior of the principal as a supervisor in analyzing the strengths and weaknesses of teachers is carried out in many ways, namely: a) Receiving information on problems from the individual concerned, either directly or indirectly; b) Listening from chatter in casual conversation; c) Having dialogues after teaching; d) Asked students about their learning difficulties; e) Discussion of solving, improvement in the class concerned; f) Receiving information from parents; g) Asked in school meetings or meetings about teaching problems faced by each teacher; h) Visiting each class in the framework of class visits; and i) Observations to class, and suggest further improvements (Suhardan, 2010)

The view of the principal of MAN 4 Muaro Jambi towards teachers who think that they are professional without paying attention to the learning carried out by the akidah akhlak teacher causes the principal to feel no need to supervise the learning process directly with continuous class visit activities.

As the principal, he should not just believe in the professional competence of the teacher, until he no longer makes class visits to observe the learning process carried out in the classroom, because it could be that his undergraduate education is not enough professional competence possessed by the teacher, and The teacher also actually needs the attention of the principal by holding class visits, and that will make the teacher more careful in carrying out the learning process if the principal is willing to observe directly in the classroom when the teacher is carrying out the learning process.

Class visits are a teacher coaching technique by school principals, supervisors, and other supervisors in order to observe the implementation of the teaching and learning process, so as to obtain the data needed in the framework of teacher guidance. The purpose of this class visit is to assist teachers in overcoming difficulties or problems of teachers in the classroom. Through class visits, the supervisor, in this case the school principal, will help with the problems he is experiencing. Class visits can be made with notification or without prior notification, and it can also be on the basis of an invitation from the teacher himself .

\subsection{INDIVIDUAL TALKS SUPERVISION HEAD OF SCHOOL}

In addition to conducting class visits to observe the learning process, the principal as a supervisor should also conduct individual talks to provide guidance to teachers who need assistance in solving learning problems so that teacher competence can increase.

The results of the data analysis research me pointing right that the head of the school MAN 4 Muaro as supervisor of education has never held talks individually with the teacher. The principal thought that the teacher at Aliyah Negeri 4 Muaro Jambi School certainly knew how to become a teacher and how to carry out the learning process, because all of their education was undergraduate and felt that it was professional enough so there was no need for individual talks or counseling. regarding the implementation of learning.

The principal's perception of the abilities possessed by teachers through undergraduate education is one of the reasons for not conducting supervision in the form of individual talks to provide counseling to teachers, but the results of observations in the field show that teachers at Aliyah Negeri 4 Muaro Jambi School do not have professional competence Overall this is proven by the fact that teachers who carry out the learning process only use the source book for student worksheets (LKS).

Professional teachers must be experienced in teaching, based on their background have a good personality, the length of the teacher's tenure and the number of lectures or seminars that are attended in the field of study they teach, mastery of the material they nurture and how to convey the material to students, the use of strategies that can help the learning process run smoothly, the use of media that is in accordance with the material to be delivered, and whether the teacher can foster good relationships with students, so that students are motivated and enthusiastic about receiving the lessons that will be delivered by the teacher.

After delivering the material, the teacher gives an assignment or conducts an evaluation so that the teacher knows the students' abilities and the extent to which the students understand the material they convey. If these components exist in a teacher, it can be said that the teacher has the criteria for being a professional teacher. 
Supervising Head of Schools in Improvement of Professional Competence Teacher

In pennies $\mathrm{n}$ gkatan professional competence of teachers through educational supervision is one of the commitments that must be developed in the educational process in general. Individual talk is an effort to find shortcomings or activities to help teachers improve and develop professional abilities so that their performance increases better and professionally. Meanwhile, according to (Mulyasa, 2005) individual talk is a guidance and counseling technique which the principal of the school / school can use to provide counseling to teachers, whether it is related to learning activities or problems related to teacher professionalism.

Individual talk is a supervision technique to provide the widest possible opportunity for supervisors to discuss directly with teachers about problems related to their personal professional (Iskandar, 2009) . As a principal, he must have high commitment and loyalty and leadership abilities through educational supervision in advancing education.

This individual discussion can be a very effective strategy for coaching education personnel, especially in solving personal problems of education personnel. But sometimes if individual talks are not carried out at the right time, it is possible to get a bad response from the teacher who feels disturbed by his privacy.

As an education supervisor, the head of the school MAN 4 Muaro Jambi only conducts individual talks by reprimanding teachers who are less disciplined when both when they arrive at school and when they start school hours, without conducting individual talks to find solutions to problems in the teaching and learning process carried out by teacher. In fact, individual talks are very important to provide opportunities for teachers to discuss problems that exist in the learning process directly and comfortably.

Teachers have a dual role in school, with the teacher's shoulders lies the quality of education. The teacher is also a managerial person who will manage the learning process, plan learning, design learning, carry out learning activities with students and control the skills and achievements of their students. Careful preparation is carried out by the teacher, in order to achieve optimal results in accordance with the learning objectives. Even though the teacher has the role of learning manager, the teacher also needs to appear as an expert who masters and is enthusiastic about the teaching material. However, all of this will not be achieved easily without the supervision of the principal, one of which is supervision by conducting individual talks.

Individual conversation can be categorized as a direct interaction between the teacher and the principal. In this interaction, a teacher is given the freedom to discuss matters related to improvements in improving his professionalism as a teacher in teaching and so on. Through this individual talk, the principal will find it easy to analyze the problems faced by a teacher, if a teacher experiences problems in the teaching and learning process and a teacher will feel happy because he feels helped in solving problems faced when teaching in class.

\subsection{SUPERVISION OF PROGRAMMED LEARNING SIMULATION}

Learning simulation is a supervision technique in the form of demonstration learning carried out by the principal, so that the teacher can analyze the appearance he observes as self- introspection. This activity can be carried out by the principal in a programmed manner, for example once a month teaching in certain classes to conduct learning simulations (Mulyasa, 2012) .

By conducting the learning simulation, it is hoped that the teachers can observe and introspect on the teaching methods that have been done so far, if it is not in accordance with the concept that should be, it must be corrected. But at Aliyah Negeri 4 Muaro Jambi School, the supervision of programmed learning simulations has not been running as it should.

From the data managed in the gather, there are several reasons why principals Aliyah 4 Muaro not supervise through simulation learning programmatically, as said by the principal : "to be honest I've never done a simulation learning programmed to teachers in school to be observed as self-introspection, because in my opinion the teachers in this school certainly know how to become a teacher, because in general they have received an undergraduate education and are equipped with how to carry out the learning process through field experience practice, so they don't. it is necessary to do a learning simulation ".

The learning simulation carried out by the principal is a form of supervision and the principal's efforts to improve the learning process, with the holding of learning simulations it is hoped that teachers will pay attention to the correct way of teaching the principal and become an introspection for teachers, but at Aliyah Negeri 4 School Muaro Jambi, the implementation of supervision through learning simulations has not been implemented. The ability 
of the principal in conducting a learning simulation should be very helpful for the success of the supervision carried out by the principal of the professional competence of teachers.

P Indonesia Economic education of increasingly advanced and models pembelajaranpun participate grown seiri $\mathrm{n} g$ the times, so that the principal should be able to follow the development of the learning process and provide a simulation of the teachers to make an introspection teachers, and not all teachers who have a bachelor it can be said of professional teachers who all know about the learning process, there may still be teachers who need learning simulations from their leaders so that they can be imitated by good teaching methods and to improve teacher professional competence.

As it is known, the principal is not only in charge of the school environment, but he collaborates with the party that oversees the institution, namely the Ministry of Religion, Muaro Jambi Regency, so that sometimes supervision time is often used in these activities. It cannot be denied that doing a job takes time, as well as the performance of a school principal, as it is known that the duties of a school principal are complex and time-consuming, which greatly affect the supervision program that has been planned.

Based on these conditions, it can be learned that in institutions, especially schools, it is very necessary to have continuous supervision carried out by the principal, because it greatly affects the smoothness and effectiveness of the learning process in schools. With the availability of time that the principal deems to be insufficient in carrying out supervision, the supervisory process carried out by the principal is hampered. Although the head of Madrasah Aliyah Negeri 4 Muaro Jambi has not carried out supervision of learning simulations as an example of teachers in order to increase teacher professional competence, the head of Madrasah Aliyah Negeri 4 Muaro Jambi has tried to complete school infrastructure to support teachers in developing professionalism as a teacher when carrying out learning activities, as well as the head of Madrasah Aliyah Negeri 4 Muaro Jambi trying to improve self-discipline in order to become an example for teachers.

Furthermore, the strategic steps taken by the head of MAN 4 Muaro Jambi in maximizing teacher discipline is to activate teacher daily attendance in order to maximize teacher discipline is one of the efforts of a principal to determine the level of teacher attendance, and with teacher absenteeism carried out every day will motivate morality of teachers to always be responsible for their duties. In the formation of professional teachers, the principal of Madrasah Aliyah Negeri 4 Muaro Jambi always provides encouragement or direction to teachers to always be disciplined in all matters related, especially in the scope of madrasas.

\section{CONCLUSIONS AND RECOMMENDATIONS}

The principal has not done his job as a supervisor optimally because the principal thinks the teacher already has professional competence that is obtained from his education so that the implementation of this supervision is not so important. The principal should make a class visit to observe the learning process directly, then conduct individual talks to solve the problems faced by the teacher, and the principal programmatically conducts learning simulations for the teacher to observe.

\section{SOURCES OF FUNDING}

This research received no specific grant from any funding agency in the public, commercial, or not-for-profit sectors.

\section{CONFLICT OF INTEREST}

The author have declared that no competing interests exist.

\section{ACKNOWLEDGMENT}

Thank you to all the people who helped in carrying out this research, I hope that what we do will benefit all people in this world. 
Supervising Head of Schools in Improvement of Professional Competence Teacher

\section{REFERENCES}

[1] Abdul Hadith, Nurhayati. Education Quality Management, Bandung: Alfabeta, 2012. Asri Budiningsih, Learning and Learning, Jakarta: PT Rineka Cipta, 2005.

[2] B. Suryosubroto, Management of Education in Schools, Jakarta: Rineka Cipta, 2010. Cholin Riches, and Colin Morgan , Human Resource Management in Education, Milton Keynes: Open University Press, 2004.

[3] Clifford F. Gray, Erik W. Larson, Project Management: The Managerial Process, New York: McGraw Hill, 2003.

[4] Colquitt, Organizational Behavior: Improving Performance and Commitment in the Workplace, New York: McGraw-Hill, 2009.

[5] Daryanto, Educational Administration, Jakarta: PT Rineka Cipta, 2010. Dadang Suhardan, Professional Supervision, Bandung: Alfabeta, 2010.

[6] Dede Rosyada, Paradigm of Democratic Education: A Model of Engagement Society in the Implementation of Education . Jakarta: Prenada Media, 2004

[7] Dess Lumpkin, Strategic Management, New York: McGraw Hill, 2003.

[8] E. Mulyasa, Competency Standards and Teacher Certification, Bandung: Youth Rosdakarya, 2008.

[9] .......... Principal Management and Leadership , Jakarta: Bumi Aksara, 2012.

[10] …...... Becoming a Professional Teacher, Bandung: Youth Rosdakarya, 2005.

[11] .........., Becoming a Professional School Principal , Bandung: Youth Rosdakarya, 2011.

[12] Fachruddin Saudagar and Ali Idrus, Teacher Professional Development, Jakarta: Echo Persada Press, 2009.

[13] Fred Luthans, Jonathan P. Doh, International Management, New York: Mc. Graw Hill, 2012.

[14] Gareth R. Jones, Contemporary Management, New York: McGraw Hill, 2003 . Helen Deresky, International Management; Managing Across Borders And

[15] Cultures, New Jersey: Prentice Hall, 2011.

[16] Iskandar. Qualitative Research Methodology , Jakarta: Gp Press. 2009.

[17] Jamal Ma'mur Asmani, Tips for Effective School Education Supervision, Jogjakarta: Diva Press, 2012.

[18] Jasmani Asf, Syaiful Mustofa, Education Supervision , J og arta: Ar-Ruzz Media, 2013.

[19] John Elliott, Action Research For Educational Change, Philadelphia: University Of Nottingham, 2006.

[20] John A. Pearce. Strategic Management, New York: McGraw-Hill / Irwin, 2007 John M. Ivancevich, Human Resource Management, New York: McGraw Hill, 2007.

[21] Keith M. Eades, The Solution Centric Organization, New York: McGraw-Hill, 2006.

[22] Kishan Badagia, Computerized Maintenance Management System Made Easy: How to Evaluate, Select, and Manage CMMS, United of America: McGraw, 2006.

[23] Kunandar, Professional Teacher : Unit Level Curriculum Implementation Education and Success in Teacher Certification , Jakarta: Rajawali Pers, 2011.

[24] Lexy J. Moleong. Qualitative Research Methodology , Bandung: Rosda Karya, 2010 . Mukhtar. Thesis Guidance, Thesis and Scientific Articles, Jambi: Sulthan Thaha Press. 2004.

[25] ......., Practical Qualitative Descriptive Research Methods, Jakarta: Reference, 2013 Mukhtar and Iskandar, New Orientation of Educational Supervision , Jakarta: GP Press, 2009.

[26] M och Uzer Usman, Becoming a Professional Teacher, Bandung: Youth Rosda Works, 2013.

[27] Martinis Yamin, Teacher Professionalization and Implementation of KTSP , Jakarta: GP Press, 2007.

[28] Maisah, Martinis Yamin, New Orientation of Education, Jakarta: Reference, 2012.

[29] Made Pidarta, Educational Foundation, Jakarta: Rineka Cipta, 2006.

[30] ......, Contextual Education Supervision , Jakarta: Rineka Cipta, 2009.

[31] Matthew B. Miles \& A. Michael Huberman. Qualitative Data Analysis, Jakarta: UI Press. 2009.

[32] Muhibbin Syah, Educational Psychology with a New Approach , Bandung: Youth Rosdakarya, 2013.

[33] M. Quraish Shihab, Tafsir Al Misbah: Message to Impression and Harmony of the Qur'an, Jakarta: Lentera Hati, 2006

[34] Muhammad Rohman, Sofan Amri, Education Management, Jakarta: Achievements Pustakaraya, 2012.

[35] Mark A. Stiffler, Performance "Creating the Performance-Driven Organization", New Jersey: John Wiley \& Sons, Inc. Hoboken, 2006.

[36] Mullin. Management and Organizational Behavior , 7 th edition, United Kingdom: Prentice Hall, 2005.

[37] Norman K. Denzin \& Yvonna S. Lincoln, Handbook Of Qualitative Research, (California: Teller Road Thousand Oaks, 2008 
[38] Ngalim Purwanto, Administration and Supervision of Education, Bandung: Youth Rosdakarya, 2009.

[39] Oemar Hamalik, Teacher Education Based on a Competency Approach , Jakarta: Earth Literacy, 2009.

[40] ........., Teaching and Learning Process, Jakarta: Earth Literacy, 2011.

[41] Piet A Sahertain, Basic Concepts and Techniques for Educational Supervision, Jakarta: Rineka Cipta, 2008.

[42] Punaji Setyosari, Educational Research Methods, Jakarta: Kencana Prenada Media Group, 2012.

[43] Ramayulis, Teacher Profession \& Ethics, Jakarta: Kalam Mulia, 2013. Richard L. Daft, New Era Of Management, Canada: Cengage Learning, 2010.

[44] Raymond A. Noe, Fundalmentals of Human Resource Management, New york: McGraw Hill, 2004.

[45] Samantha Chapnick and Jimm Meloy, Renaissance Elearning , United State: Pfeiffer, 2005

[46] Syamsuddin, Vismaia S. Damaianti, Language Education Research Methods, Bandung: Youth Rosdakarya, 2007

[47] Syaiful Bahri Djaramah, Learning Psychology, Jakarta: Rineka Cipta, 2011.

[48] Sri Banun Muslim, Education Supervision to Improve the Quality of Professionalism Teacher , Bandung: Alfabeta, 2010.

[49] Soetjipto and Raflis Kosasi, Teaching Profession, Jakarta: Rineka Cipta, 2009 . Syaiful Sagala, Supervision of Learning in the Educational Profession , Bandung: Alfabeta, 2010.

[50] ......... Professional Abilities of Teachers and Education Personnel , Bandung: Alfabeta, 2009

[51] .........Contemporary Educational Administration, Bandung: Alfabeta, 2012. Soedijarto, Teacher Professionalism in Challenges, Jakarta: Rajawali, 2004 Sugiono. Qualitative quantitative research methods and R\&D , Bandung: Alfabeta 2010 .

[52] ........., Understanding Qualitative Research, Bandung: Alfabeta, 2008. Suharsimi Arikunto . Research Procedure A Practical Approach , Jakarta: Rineka Cipta , 2010.

[53] Sudarwan Danim, Khairil , Educational profession, Bandung: Alfabeta, 2012.

[54] S. Margono. Educational Research Methodology. Jakarta: Rineka Cipta, 2005. UPI education administration lecturer team, Education Management, Bandung: Alfabeta, 2012 .

[55] Udin Syaifudin , Teacher Professional Development, Bandung: Alfabeta, 2010.

[56] Wahyudi, Principal Leadership in Learning Organizations (Learning Organization), Bandung: Alfabeta, 2012.

[57] Wina Sanjaya, Educational Process Standards Oriented Learning Strategy, Jakarta: Kencana, 2011.

[58] ........, Learning in the Implementation of Competency-Based Curriculum, Jakarta: Kencana, 2006.

[59] William J. Stevenson, Operations Management, New York: McGraw Hill, 2003. 